\title{
ALCOHOL CONSUMPTION PRACTICES IN THE KORYAK COMMUNITY
}

\author{
LYUDMILA N. KHAKHOVSKAYA \\ Candidate of Historic Sciences \\ The North-East Interdisciplinary Scientific Research Institute n. a. N. A. Shilo \\ Far East Branch of the Russian Academy of Sciences (NEISRI FEB RAS) \\ 685000, Magadan, Portovaya str. 16 \\ e-mail: hahovskaya@mail.ru
}

\begin{abstract}
The article ${ }^{*}$ is dedicated to the analysis of alcohol consumption practices within the Koryak ethno-cultural community. The aim of the article is to understand how the reasons for alcohol consumption are explained within the framework of the community. The analysis is based on the ideas of Durkheim's social theory. The author of the article claims that the practice of consuming alcohol is essentially connected with the more archaic practice of mushroom consumption since both have a grounding in the Koryak perception of the world. The analysed models of behaviour stem from appropriate Koryak epistemology and ontology, which themselves are based on the notion of the 'other world' and communication with supernatural entities (spirits). The isomorphism of consuming alcohol and amanita intoxication reflects the inner core of this connection: the Koryak believe that an entity enters the human body and controls their actions. The transition from one type of intoxication to another is accompanied by drastic transformation of the materiality of the consumed product, which, in turn, leads towards social transformations. Such social changes are qualified as anomie by the author of the article. The visual materiality of the amanita mushroom dictated its symbolic anthropomorphism and creation of special rules for the treatment (amanita codex). The physical amorphousness of vodka does not imply the same intellectual work. The author claims that this factor was one of the reasons why the Koryak do not have social regulations about vodka consumption - which leads to mass alcoholism. It is possible that indigenous communities have difficulties in working out the required social regulations because of the complexities surrounding the non-utilitarian treatment of the unusual materiality of vodka.
\end{abstract}

KEYWORDS: the Koryak; other world; supernatural entities; alcohol; amanita mushroom; sacredness; social factors; material features.

\footnotetext{
* I thank Aimar Ventsel for inviting me to the Arctic Workshop at the University of Tartu. I am sincerely grateful to Igor' Yevgen'evich Vorobey for his help in writing the article and sharing his fieldwork materials, pictures and archive notes. I thank my son Dmitry Zhukov for the English translation of the article. This study was prepared with the support of the grant of the Russian Foundation for Humanities (project RFH 15-41-93032).
} 


\section{N T RODUCTION}

This article is dedicated to the analysis of alcohol consumption practices within Koryak ethno-cultural community. The aim of the analysis is to understand how the reasons for alcohol consumption are explained within the framework of the community. A field case attracted my attention to this topic more than ten years ago, although the detailed research started later, when I prepared my presentation for the Arctic Workshop at the University of Tartu, titled Responsibility and Authority in Drinking, held on May 30-31, 2014.

During the research period, I found matters that persuaded me to move beyond the limits of the contemporary sociocultural context and study this topic from a historical perspective. I saw how bizarrely the indigenous people perceive their behaviour to be when under the influence of alcohol for the first time in summer 2002 when I travelled from Evensk to Gizhiga village in a tractor trailer. ${ }^{1}$ A group of Gizhiga inhabitants (gizhigintsy) consisting of Even, Koryak and Kamchadal men also headed to the village. On the way they drank some vodka, began to swagger and then, in response to my protests, one of the natives said: "This is not me acting, this is the vodka in me acting". That was pronounced with full gravity, although with a sense of shame for such bad, 'not-his', behaviour. That case led me to the conclusion that the natives in this area perceive the person's unusual behaviour as an intervention of an outside power. It is noteworthy that this external power is individual for every human being. It seems as though an entity from outside, corresponding with the situation, enters the person's body for a while to control his or her thoughts and actions.

According to the Koryak idea, the world is inhabited by various spirits and a human being is attacked by an evil spirit they call a ninvit. When realising the presence of an external entity in the body, the owner of the body does not fight the temporary suppression of personality and does not dispute the right to give or, it would be better to say, share the soul with the temporary guest. The person is practically split apart in his or her own feelings and fixes this ambivalent status by any means possible. It is significant that other aborigines do not criticise such abnormal behaviour, considering it quite legitimate.

Carrying out periodic fieldwork in Severo-Evenskiy district I encountered such explanations of the drunkenness in the indigenous people themselves. Beyond this, my attention was caught by the communal refusals of alcoholic and narcotic substances (tobacco, spirits) that have taken place among the Koryak people of the Magadan region in the last decades. This refusal was inspired by their conversion to the Protestantism and membership of the Pentecostal church. My fieldwork focused on the western group of Koryak people living in the Magadan region. I also use the archive material and literature regarding Koryak people found in different regions of Kamchatka.

The following sources are used as a basis for the research: texts (archive documents and publications); oral information (interviews); and data gathered during the fieldwork. The last two sources cover the contemporary period, while the texts bring to us events of different periods, giving this research chronological depth.

I will use Emile Durkheim's (1964 [1895]) social factor theory. According to Durkheim, behavioural rules, shared by a community, possess binding force and do not 
depend on individual attitudes) for a theoretical explanation of alcohol consumption practice amongst Koryaks. Durkheim considers social factors as evolving through time, transforming into other forms but not losing their essential features. The social factors statement allows us to believe that consumption of alcoholic beverages is essentially tied with the more archaic practice of amanita mushroom narcotisation since both practices have an explanation in the Koryak worldview. With the help of archive documents and field materials I will illustrate how the abovementioned behaviour models come from appropriate Koryak epistemology and ontology, and are connected to immanent ideas of the other world and communication with supernatural entities (spirits).

The central idea of Durkheim's social theory is the statement about sacral phenomena being perceived as universal, inseparably associated with any society (Durkheim 1965 [1915]). Sacred beliefs, according to Durkheim, are always rational because they appeal not to the natural but to the social world. Durkheim differentiates between materialistic and non-materialistic social factors. The former are backed up with existent material infrastructure while the latter are products of collective symbolic activity. I want to show that the switching from eating amanita to drinking vodka was accompanied by a qualitative change in the physical characteristics of the toxic substance. This was an important reason for changes in the social regulations of narcotisation practices.

Koryaks have strict rules, and accepted ways, of reflection about men's behaviour under amanitas. Society recognises the right for only particular people to eat mushrooms, however episodically anyone can eat amanita. I assume that the efficiency of social control over this practice is determined by the material and visual persuasiveness of amanita activity, which presents itself as an entity absolutely equivalent to human. According to the Koryak and Chukchi people, amanitas gather into communities like humans and have their own will, expressed during communication with humans (Bogoraz 1939: 5). According to this, material existence of amanitas and their imagined personality strongly back up the efficiency of social sanctions.

At the same time, vodka drinking does not involve any significant reflection within Koryak society since the amorphousness of the physical beverage obstructs any symbolism that could lead to the creation of social norms. Although the Koryaks have been familiar with vodka for more than three centuries, their cultural perception of alcohol remains very simple and does not go beyond the point of recognition of its spiritual power. From this perspective, alcohol consumption amongst Koryaks can be classified as anomia, based on an asymmetry between its consumption and its intellectual perception within the framework of the traditional Koryak worldview. In the final part of this study I shall deal with the fact that Protestant (Pentecostal) missions amongst the Koryak appear to be a significant force in the regulation of alcohol consumption.

\section{THE ONTOLOGICAL AND COGNITIVE BACKGROUND FOR HALLUCINOGENIC PRACTICES}

It is necessary to underline how the identification of non-material entities is absolutely normal, natural, and, to a certain degree, operational for the Koryak. Moreover, the association of sacred and social matters, theoretically grounded by Durkheim, points to the importance of communication with the other world for the indigenous people. 
The meaning of this communication goes beyond the individual spiritual area and is projected onto the wider range of social facts.

I would like to demonstrate that Koryak hallucinogenic practices conceal models of behaviour that are strongly connected with their intercommunication with the nonmaterial world and have a solid ground in religious ideas and views. However, the development of religious ideas is, in turn, related to the comprehension of observed natural phenomena, which are approached rationally, by intuition or through altered states of consciousness. Researchers claim that the absence of a clear natural ontology restricts development of religion drastically (Boyer 1994). The coherence of ideas about both the non-material and material worlds secures a cognitive optimum in society that is favourable for the maintenance of social order.

The Koryak worldview includes the following basic ideas: 1) the existence of other worlds; 2) these other worlds are inhabited by spiritual entities; 3) the Earth world and other worlds can interpenetrate. The Koryaks personalise the spiritual entities, determine a hierarchy, and assign moral qualities among them (kind and evil spirits). Many literary sources are dedicated to this issue (Antropova 1976; Vdovin 1979; Lebedev and Simchenko 1983; Gurvich 1987). Unpublished manuscripts by Konstantin Ivanovich Bauerman $^{2}$ shed some extra light on this problem. Here is an excerpt from his notes:

They think of a soul as of a bodiless though very mobile shadow, like a breath, like a spirit. Parenetsy ${ }^{3}$ believe that when they are asleep, their souls, alter egos, leave their bodies. However, sometimes the soul can stay within the body. [...] And all that is seen and told in a dream the parenets imagines as being real and feasible. [...] When a man dies, his soul continues to live. It just abandons the dead shell and travels to the Pynennelo - the place where all parenets' souls dwell. [...] they also know a whole host of gods. Some of them are prime, others are inferior, some of them are kind to a parenets, others are mean and try to harm people.

The main kind divinity that always lives in heaven (or, as a parenets said, "in a light") is Edna. His helpers in heaven are Kagyitelan and Kun'yailatyllaan. [...] the evil divinity is called Toienyultynyllaan - a devil who always lives on Earth whose helper is Ningvingysnen (also known as Kamak). The latter is kind of a fetish among the parentsy and is a worn on clothes by children, men and women. [...] Should a Koryak have a bad dream, he sacrifices a dog to the spirit that talked to him in the dream. Should a parenets feel better after a long illness, he sacrifices a dog to the glory of the god who removed the evil spirit. (GARF F. P-3977, 1. 1, f. 448 , pp. $14 \mathrm{v}, 15,15 \mathrm{v})$

Hence the Koryak admit the power of spirits to enter a person's inner space for a short (dream) or for a long (illness) period. Acceptance of such spiritual power is a characteristic feature of the Koryak worldview even today. However, the Koryak do not formulate their ideas neatly, but rather these ideas are manifested by their ceremonies and everyday behaviour.

I now focus on some significant points that characterise the religious worldview of the Koryak people. First of all, the Koryak views on evil spirits are ambivalent. For example, one can point to Ningvingysnen, the harmful entity whose name has become generic - the Koryak call all evil spirits ninvit (Stebnitskiy 1930: 42). At the same time the Koryak also believe in Kamak, the spirit defender against evil, whose image is worn 
on clothes for protection. ${ }^{4}$ Hence evil is not absolute and different spirits are related to it in various ways (Jochelson 1905: 30, 35; Antropova 1976). Thus, representatives of the other world cannot be unambiguously determined as good or bad (kind or evil). Simple and final determination does not correspond with Koryak beliefs because inversion and simultaneous recognition of oppositional features is possible in their worldview. Accordingly, the Koryak do not evaluate or label the entity that comes from amanita or vodka consumption unanimously as kind or evil.

Secondly, the Koryak do not perceive death as something evil or as a punishment but only as a transition (Vdovin 1979: 90). The Koryak believe that the departed person will be reborn in descendants, i.e. they believe in the circle of life. The Koryak sincerely see their departed ancestors in their children. This is proved by the ceremony of giving names (Orlova 1929: 93; Dedyk 2006), rituals that are held today as well (Kurebito 2008). This leads to the fascinatingly calm attitude of Koryak people to death. ${ }^{5}$ Scientific evidence concerning the harmful influence of narcotic substances thus has little impact on Koryak practices of amanita mushrooms and alcohol consumption.

Thirdly, the Koryak believe that spirits act as active social agents. Spirits are often considered to interact with each other, but they also fight against their own kind. This can be most vividly illustrated in actions related to amulets. According to the Koryak, amulets can enlarge themselves for better effect during a fight or turn into traps. The fight between spirits can happen in secrecy, for example, during human illness. To control such contact the Koryak adopted a set of special rules that include mushroom eating (amanita codex).

Finally, the fact is that such a set of rules leads to the development of consensus in society, which is maintained because the comprehension of certain events contributes to a common Koryak worldview. This is why the Koryak people pay significant attention to daily situations - every once in a while the Koryak reveal their sacral side. Sacralisation of the environment is always object-oriented. A man can discover a sacred object in the surrounding environment during unusual situations, yet according to Koryaks the object presented itself. Such an appearance is a signal from a supernatural power. Sacral object can be manufactured if a man gets instructions while being in altered state of consciousness (for instance during a dream). This is why Koryak culture is rich in different amulets: forks, wooden dog figures, soft dolls, stones, buttons, bead roses, etc. (Khakhovskaya 2014; see Photo 1). So, the nature of sacral matters is connected with individualisation of objects and events.

Due to the cognitive selectivity of the perception of nature and transcendent phenomena the Koryak associate their lives with a coordinate system that is different to that adopted by the non-indigenous inhabitants of the region. They invest the world with categories that they have becomes used to and that are reflected in the practices of amanita mushroom and alcohol consumption. 


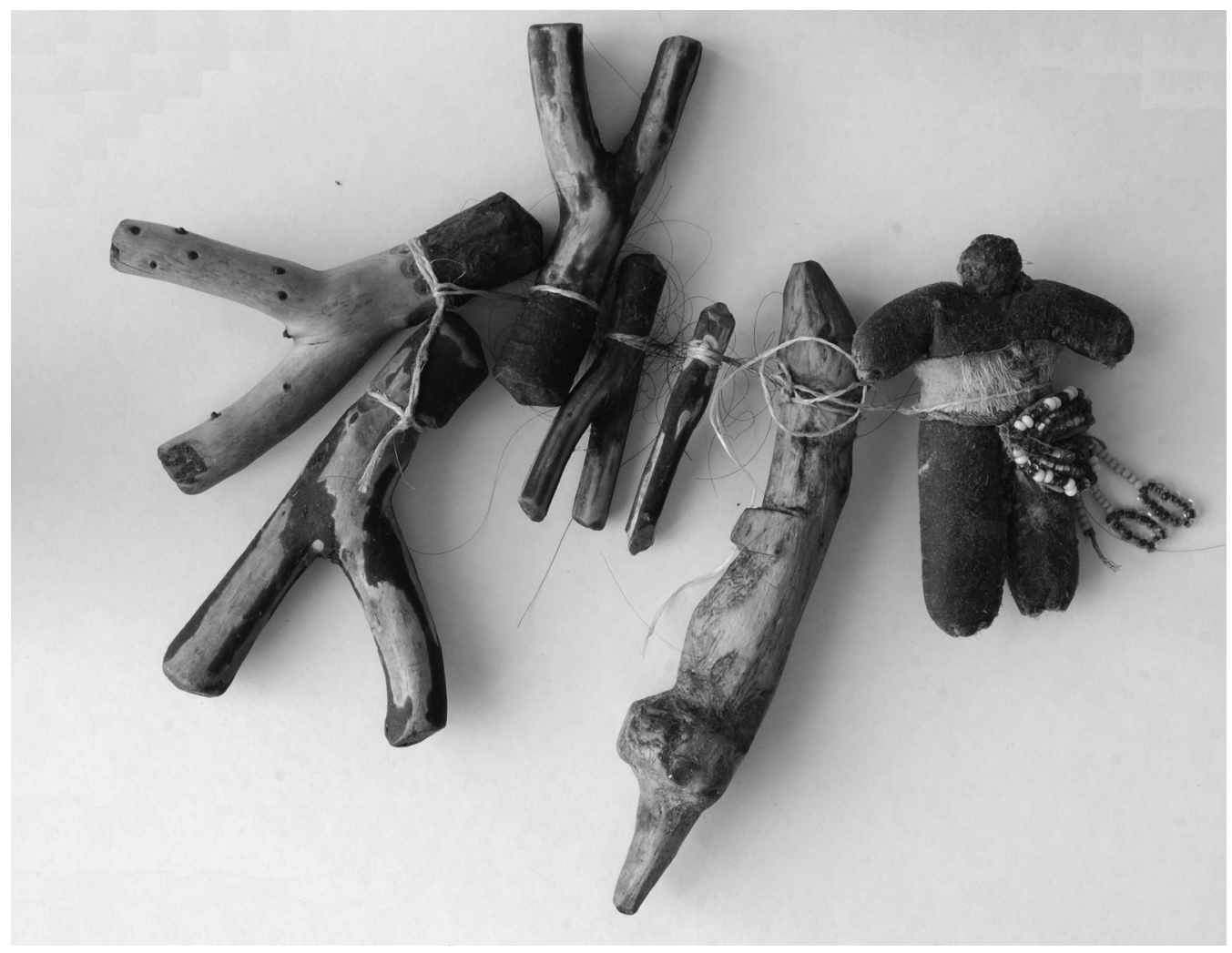

Photo 1. The Koryak guardians from ritual bunches (Khakhovskaya 2014: 98).

\section{KORYAK AMANITA MUSHROOMS PRACTICES}

The usage of hallucinogenic mushrooms implies a collectively experienced approach to the world and a mastery of social control over people's behaviour. The condition of man that is under narcotic effect (in local expression, "under amanitas") was explained as a connection with the other world and spiritual beings. According to such beliefs, a person's behaviour as they prepare to eat mushrooms was treated as a special code where the amanita itself set the rules. Some points of that code could vary, but ethnographic evidence proves its imperative character for the Koryak (Vereshchaka 2014).

The Koryak believed in the spiritual power of the amanita mushroom and how it controlled people's behaviour. A member of the Jesup North Pacific Expedition, Dina Lazarevna Brodskaya-Jochelson, wrote about such a situation (the record is dated November 8, 1900, the location was the Koryak village Kamenskoe, in Gizhigiskii Okrug):

[...] a lot of reindeer Koryak arrived, Chukchi are here, as well as one Lamut. [...] all guests along with the hosts are under amanitas. [...] Igei is under amanitas too. His hands are shaking, eyes are shining unnaturally; he is seeing things; he walks, speaks and nods off repeatedly and beats the drum. Amanita tells him what to do. 
[...] When under amanitas, people are not responsible for their actions, amanita is in charge and all the things people imagine while intoxicated are shown by the amanita. (AIVR F. 23, 1. 2, f. 129, pp. 5v, 6)

Anthropologist Il'ya Samuilovich Gurvich recorded in his diary Koryak Ivan Stepanovich Taynav's opinion about the effect of the mushroom effect (dated July 20, 1969; Achayvayam village, Olytor rayon, Koryak okrug): "A man who eats amanita becomes very strong. Amanita tricks him (hallucinations). The man does not feel tired or predict future." (AIEA F. 44, 1. 7, f. 1109, p. 25) I suppose this opinion reflects long experience of mushroom consumption. According to the images of human-shaped amanitas in the Pegtymel petroglyphs (Chukotka), indigenous people of the Siberian Far East have been familiar with effects of the mushrooms for at least one thousand years (Dikov 1971: 36-50). Perhaps, because of such a long period and collected experiences, the Koryak are able to intellectually comprehend their condition during amanita intoxication and create a set of spiritual rules for communication with the mushroom.

According to the indigenous inhabitants of the Siberian Far East, the amanita mushroom is personified as supernatural, but tangible, matter with synthetic morphology (with both human and mushroom features). The physical features of the mushroom generate bright visual associations and mental interpretations since it has a specific shape, bright colour and thick structure. Hallucinations induced by eating amanita supposedly express the pictures of body contact with the mushroom. As a result, the Koryak think that the amanita is equal to humans because it has an anthropomorphic figure and acts like a partner. These ideas have visual expression - on the rocks of Pegtymel there are images of couples consisting of a human and human-shaped amanita holding hands (Dikov 1971: 26).

It is believed that the spirit of the amanita can replace the human spirit, that is why people identify themselves with the mushroom when under amanita. For example, once Atkin, a Koryak, was drying amanitas, placing them on open spaces and covering them with twigs. When the mushrooms were dry, Atkin ate them, then lay down and covered himself with the tree branches. His behaviour had somehow gained features of the amanita mushroom. ${ }^{6}$ Other similar cases are reported by other researches (see also Bogoraz 1991: 141).

Communication with the mushroom is enjoyable and beneficial. The mushroom endows one with extraordinary powers that are hard or impossible to gain in other ways. One gets access to secret knowledge, becomes strong and agile. Witnesses say that under amanita people begin to climb trees "like squirrels", walk on smouldering bonfire coals with no harm, and that they "fly" and "see" things in other places and times. $^{7}$

This partnership between human and amanita had existed for centuries, fulfilling two basic social needs: prediction of the future and facilitation of hard work. The circle of people with rights to eat amanita is strongly limited to those who possess sacred knowledge (shamans and their helpers, i.e. mainly older men) and those who carry out hard work like hide tanning, transportation of heavy loads or searching for reindeer. This, however, does not mean that no one else may eat mushrooms on special occasions, for example, holidays.

In parallel to this, the effect of this hallucinogenic mushroom is considered dangerous. In the view of the native people, this danger is connected with the mushroom's 
ability to trick, punish or even kill using the power of its own will. Amanita is such a sophisticated organism that it can have servants among the spirits acting on its behalf. These spirits, like the mushroom, have a material appearance, and the effectiveness as a punishment measure is fully accepted by the Koryak people. It is impossible to predict or prevent such events - all is a game of odds. For instance, one Koryak informant told of how, as far as he could remember, three male Koryaks and one female Chukchi died after they ate amanita. The informant himself nearly died too. According to him, he ate mushrooms one by one with no effect and all of a sudden everything went black for him. ${ }^{8}$ The Koryaks consider that spirits living in the mushroom as worms can kill people (Iokhel'son 1997: 114). Such a case is described by Brodskaya-Jochelson (the record is dated November, 8, 1900, location: Kamenskoye village):

Last year one Koryak man ate ten mushrooms at a time with no effect, but when he ate another one, he staggered, threw up and died instantly. Petr [a Cossack from Gizhiga] was a witness and said afterwards that his vomit consisted of live worms that swarmed; [...] Petr expressed it this way: "These worms killed him and left him". (AIVR F. 23, 1. 2, f. 129, pp. 5v, 6).

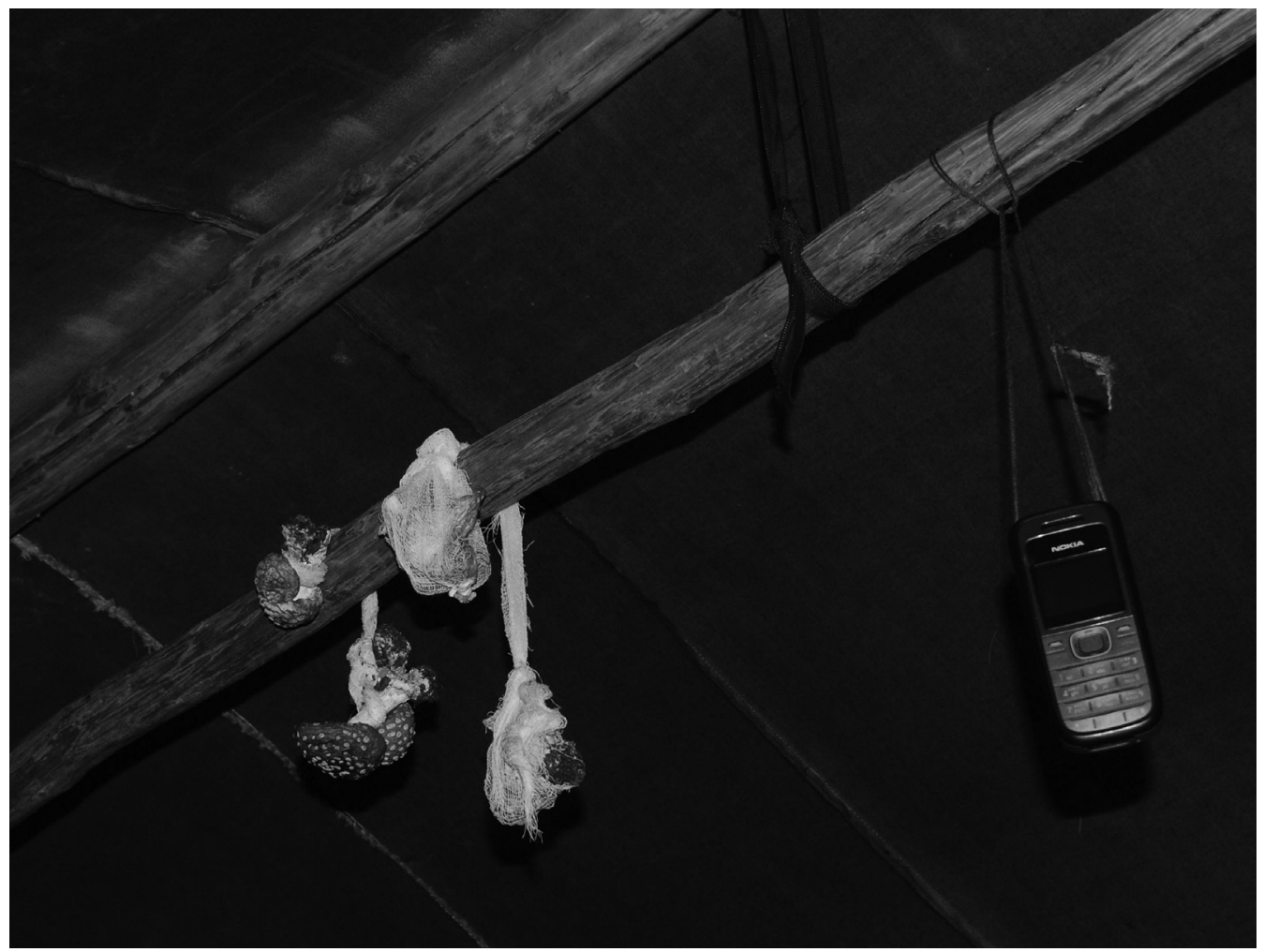

Photo 2. Amanita dried in a Koryak reindeer herder's tent. Severo-Evenskiy district, Magadan region; September 8, 2010. Photo by Igor' Yevgen'evich Vorobey. 
Field materials and research show that the Koryak continue to prepare and eat amanitas (photos 2 and 3). Amanita practices involve the association of sacred and social matters that can be treated, according to Durkheim (1965 [1915]), as universal features of religious life. The experiences of people who eat mushrooms on a regular basis becomes the property of the whole community that shares the same ideas about supernatural entities within material objects. Metaphysically amanita is considered a visitor from the other world, providing the opportunity to go beyond daily experience. The Koryak assume that the nature of the amanita is identical to human nature, but this anthropomorphised mushroom is quite a contradictory creature for them: on the one hand, it is a helper, partner and cheerful mate, on the other a tricky deceiver. A specific dynamics of amanita consumption is stipulated by the fact that mushrooms are used not only for spiritual purposes, but also for stimulation (hard work). Koryak society controls the practice, emphasising specific social categories that have permission to eat amanitas. Alcohol drinking practices, in turn, do not have any elaborated reflection and social control in Koryak society.

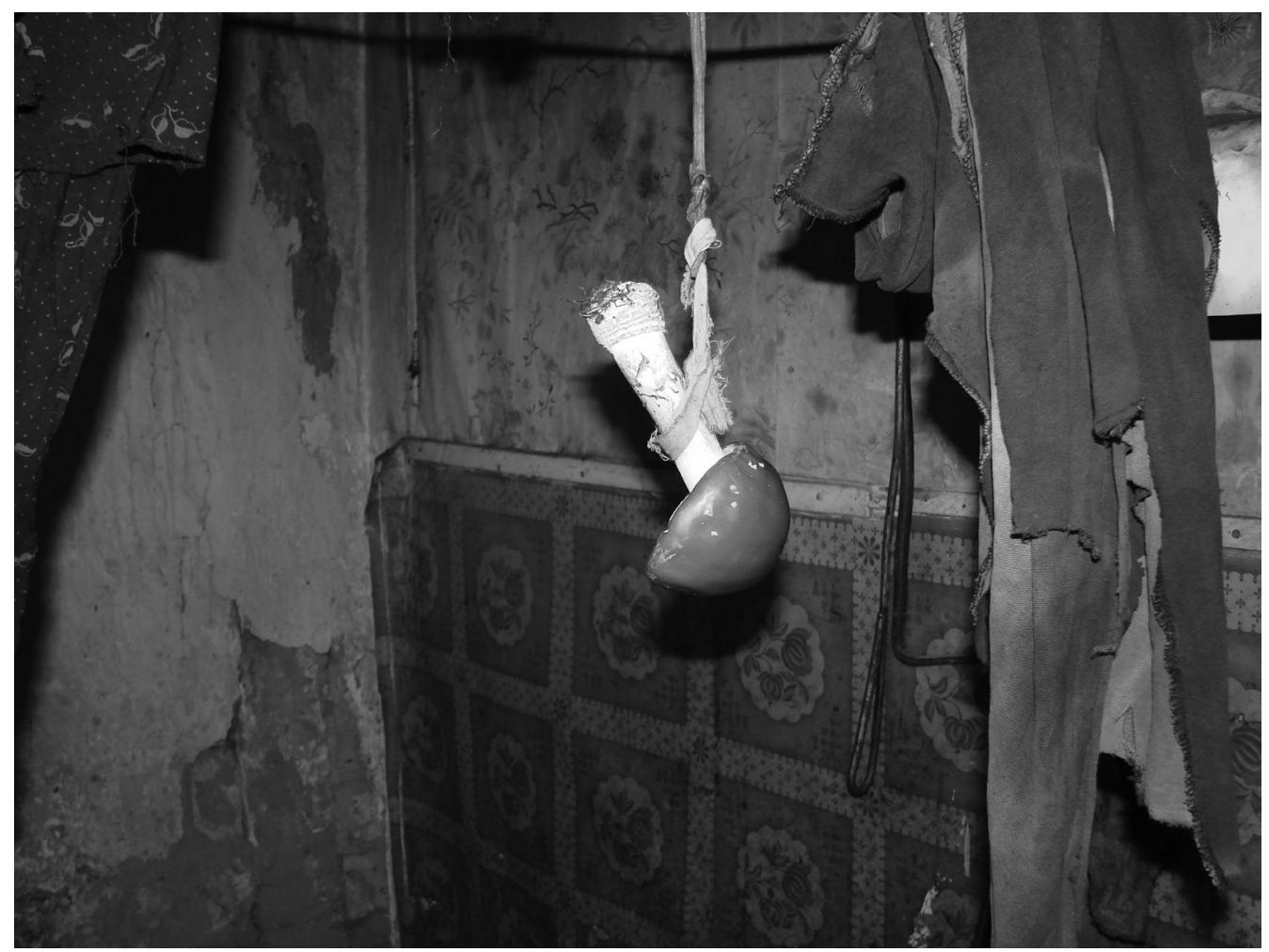

Photo 3. Amanita dried in a farmhouse. Verkhniy Paren' village, Severo-Evenskiy district, Magadan region; August 13, 2011. Photo by the author. 


\section{ALCOHOL PRACTICES AMONG THE KORYAKS}

It is not fully known how alcohol entered Koryak culture. However, on thing is obvious, the spread of alcohol was a side effect of the indigenous group's contact with European culture, which happened in two ways: trading (barter) and treat. The tradition of drinking alcohol was accompanied by hierarchy building within the indigenous communities. Russian authorities put some people in charge among the aborigines. They had certain titles: prince, captain, steward (knyazets, starosta, starshina). These people were in trading relationships with the Russian administration.

Igor' Yevgen'evich Vorobey found documents that fixed an event at which the Chukchi drank vodka for the first time. This was on March 4, 1778 (according to the Julian calendar) in the town of Gizhiginsk, where a protocol was signed. Since then the Chukchi have been subjects of the Russian Empire. The Chukchi were represented by their chief (toyon) Amulyat Khergyntov. Due to this occasion a thankful prayer was performed along with a cheerful event with music, dancing, drinking and cannon-fire. The Koryak chiefs were there as well. According to the document, the Koryak already had some experience of vodka drinking, so they were not allowed to drink much for security reasons (RGADA F. 199, no. 539, 1. 2, f. 6, pp. 1, 14, 14v). For instance, on March 23, 1778 the Koryak chief Muykeg'i Engilin was "drunk as hell" and started a fight with Koryak Nutela Ivilin next to the eastern gates of Gizhiginsk town (RGVIA F. 14808, 1. 1, f. 73, p. 2v). The Captains of Gizhiga fortress did not allow Koryaks to drink much in order to stop them doing anything bad when drunk (RGADA F. 199, no. 539, 1. 2, f. 6, pp. 1, 14, 14v).

By the end of the 18th century alcohol became a regular part of Koryak and Chukchi life. Karl Merk reported his observations in 1791: “The Koryak people call vodka AchaMitill ('bad water'), though they will learn to love it soon" (Merk 1978: 143). However, only a limited circle of Koryak clan elders drank alcohol.

At the beginning of intercultural and interethnic dialogue between the native people and Europeans, alcohol was consumed only by the upper classes of indigenous society. Since the product was not familiar to the majority of Koryak people, culture-specific regulations for alcohol consumption were not needed. A hundred years later the situation changed. Indigenous people learnt the taste and effect of alcohol, which changed the core of the practiced narcotisation - Koryaks tried to substitute vodka for mushrooms. According to Vladimir Il'ich Jochelson, Koryaks preferred amanita to vodka at the beginning of the 20th century (Jochelson 1997: 115). However, from the journals of his wife Dina Brodskaya-Jochelson we learn that at the beginning of the 20th century the Koryak valued alcohol highly. Vodka was "the highest thing on the earth" to the Koryak (AIVR F. 23, 1. 2, f. 129, p. 14). Here is the passage from her journal from September 28, 1900 (from Kuel' village):

All [of the Koryak] chew tobacco, even women and children, and happily take it for exchange. The second bait is sugar, but the most valued thing is vodka. They would sell their soul for vodka. If asked what he wants to get for a mask or other artefact, the answer would always be: "Vodka, more vodka, for my head to go round". (AIVR F. 23, 1. 2, f. 128, p. 51v) 
It must be clarified that the term mask means gypsum face mask, with which the Koryak parted very reluctantly. In this case vodka was the ultimate reason on the hands of the researchers. One more passage from the journal of Dina Brodskaya-Jochelson from October 30th, 1900 (from Kamenskoye village):

Today Vladimir Il'ich [Jochelson] took a mask from the face of Khagilkhut. He refused. Vladimir Il'ich had to persuade him and he agreed only with "vodka for the head to go round". [...] They all go crazy about vodka and sell their souls for it. One more passion is eating amanita mushrooms if they get them. (AIVR F. 23, 1. 2, f. 128, pp. 89, 89v)

Therefore, vodka was valued more highly than sugar or tobacco and was as popular as amanita mushrooms.

By the beginning of the 1930s, amanita and liquor were equally attractive to the Koryak people. The manager of the Koryak kul'tbaza (located near Penzhino village, observation time 1930-1931) reported:

Apart from amanita, home-made vodka (brazhka) has great success among the Koryak. They brew it with berries or sugar and flour. Strong alcohol is very familiar to them. The Koryak do take wine as well, but always prefer something from the three above. ${ }^{10}$ (GARF F. P-3977, 1. 1, f. 1112, pp. 124, 125)

In the Soviet period massive alcohol consumption was encouraged by infrastructural availability. The majority of the Koryak settled in villages and towns, where manufactured alcohol or surrogates were available. The ethnographer K. I. Bauerman witnessed how hooch brewing was a common activity among the Koryak of Paren': "They drink tea with no sugar, because sugar is used for braga or burduk brewing. These beverages are like hooch (samogon) and attract all local people (both Koryak and Russian)." (GARF F. P-3977, 1. 1, f. 448, p. 11) Anthropologist I. S. Gurvich worked in the Koryak village of Karaga in 1971 and noticed:

Drinking is a huge problem. Vodka from 10 am to 8 pm. [...] They also drink perfume and after-shave lotion. Vodka is delivered to the village foremost. If there is no vodka, they send complaints to Petropavlovsk or Moscow. [...] Visitors are sent back for boozing; locals must be instructed to improve their behaviour. (AIEA F. $44,1.7$, f. 1116, p. 8)

Researchers have noted some common features in daily consumption of amanita mushrooms and alcohol. Long-lasting narcotisation typical to alcoholics was also witnessed among amanita consumers: "Some eat amanitas for the whole month or even the whole winter and are constantly high" (AIVR F. 23, 1. 2, f. 129, pp. 5v, 6). The same with vodka: "The Koryak drank their own urine after drinking vodka to keep up their condition" (Iokhel'son 1997: 114).

Amanita and alcohol function in a similar way in the context of spiritual acts, such as shamanistic rituals and predicting the future. Both shamans and non-shamans perceived intoxication as a contact condition. Nikolay Nikolayevich Beretti (1929: 25) who worked among the Koryak in 1924-1925, wrote: 
Once I had to watch one native person who drank a quart of vodka, took off his clothes when it was 20 degrees below zero outside and started to roll on the snow. He made some drunken noise that others treated as predictions of the future.

Vodka and amanita became equal in sacral significance. The Koryak consumed them simultaneously during religious celebrations. Yelizaveta Porfir'yevna Orlova, who worked among the Koryak in 1926-1927, wrote in her field diary: "If the celebration goes on for two or three days, then during both the second and third days they continue to fight, play drums, play cards, drink spirits, eat amanitas. When high, they always talk much and stop only to play a drum." (GAFR F. P-3977, 1. 1, f. 448, p. 117)

Identifying the effects of amanita and alcohol, as noticed by ethnographers, is obvious. Scholars observed primarily the evident features of behaviour and preferences. My research materials also confirm that shifts in consciousness and behaviour brought on by amanita and alcohol are strongly connected and indicate similar worldview settings. In other words, similar spiritual experience are reflected in both practices.

Nevertheless, there are also significant discrepancies in the cognitive and sensual perception of both amanitas and liquor. I presume that the Koryaks were, in some way, defenceless in front of vodka because of its amorphousness and facelessness. Alcohol, despite having a similar effect to amanita mushrooms, has an absolutely different shape - or, to put it another way, it has no shape. Vodka's material existence is not obvious, especially for aborigines. Vodka is liquid and so does not bring associations to aborigines' minds. Therefore, in their eyes alcohol is a faceless substance with no characteristics.

The mushroom has a physical form and agency outside the human body. Its nature and subjectivity is projected onto the other world inhabited by amanita's nation. Amanita's appearance is always mysterious, situational and exists due only to its own will the mushroom shows itself on purpose to give orders, sometimes to punish, and sometimes even to kill. In contrast, vodka's 'activity' can be perceived only within the body, when drunk. Culture-specific ideas about alcohol did not appear because of this material intangibility. And for this reason the Koryak experience trouble when attempting to articulate the entrance of the alcohol spirit, except in very common and trivial ideas and analogies.

I presume that the cognitive and sensual aspects described led to a degradation in social norms, and the subsequent anomia had a significant impact on alcohol consumption. In other words, the Koryak social arsenal did not include a proper codex, or spiritual specialists like shamans, who could help in the social treatment of alcohol. Rehabilitation or community influence had little effect in the fight against massive alcohol consumption, which we can still see among the Koryak today. Sometimes alcoholism begins at a very young age so that by the time people are adults, they already have great experience of drinking. For example, one Koryak woman told me: "I quit drinking and smoking when I got married". ${ }^{11}$ The absence of gender and age differentiation in alcohol consumption contrasts with selectivity when it comes to amanita eating - the Koryak consider it unwelcome for youths and women to eat mushrooms. Exceptions were made for those who demonstrated shamanic talents (they could eat amanitas constantly) and for those who carried out hard work (in this case not constantly). Vodka can be substituted for mushrooms in shamanic practice, but does not suit hard work at all. 
I argue that the fight against alcohol is unsuccessful partly because of the fact that rational reasons like serious illness or premature death do not have much effect on the Koryaks. Only a few Koryak are afraid of dying (and are taunted by others for this). Since the Koryak do not fear death, life and health are not treated as separate values. One Russian informant expressed the following opinion: "the Koryak value neither their own lives, nor the lives of others".$^{12}$ The Amanita codex was created not to limit illness or mortality, but to regulate relationships with inhabitants of the other world.

This brings us to the issue of Durkheim's (1965 [1915]) dichotomy, dividing cultural phenomena into sacral and profane. Within the framework of my topic this can be seen as a dichotomy of culturally framed and incomprehensible phenomena, according to a traditional worldview. The efficiency of social control in communities like the Koryak very much depends on the interpretation of the other world, and such thinking is related to the visual and materialistic features of sacred objects. Traditional Koryak religious ideas provide only superficial explanation of alcohol addiction through general recognition of an intangible entity (the spirit of vodka). However the activity of the vodka spirit is practically not included in social life and collective mentality apart from occasional episodes of clairvoyance by drunken people. This social-religious background functions as a destructive condition that fits in Durkheim's (1964 [1895]) definition of anomia. Alcohol addiction cannot be controlled by traditional social or religious rules and intra-ethnic motivation for elaborating new norms is rather low.

Everyday matters in Koryak life cannot be divided strictly into categories of sacred and social, as was done by Durkheim. Durkheim provides a clear differentiation of these two areas in order to draw a direct projection between them: religious notions reflect the concept of an ideal, desired community, and religious practice confirms the understanding of such a community. However, as noted earlier in this work, the other world of the Koryak interferes with reality materialistically and spiritually, corrects social processes and influences social business. The connection between religious and social worlds is obviously more complicated, asymmetric and flexible because of the issues of discrepancy and the poor comprehension of new social phenomena (such as, for example, alcohol consumption).

\section{CONCLUSION}

In this article I demonstrate that the isomorphism of alcohol intoxication and amanita intoxication, diagnosed on the base of observed behaviour, reflects the inner essence of this connection. During my research I revealed a key peculiarity of the Koryak worldview and behaviour in terms of alcohol consumption - the Koryak perceive their condition under alcohol as being possessed by external powers. This kind of perception implies personal detachment from misconduct committed under the effects of alcohol. A person acts in the interest of this unknown power, which removes all moral limits and serves as an excuse for deviant behaviour.

The vodka spirit, like the amanita spirit, is not recognised as definitely harmful and dangerous due to ambivalent Koryak ideas about the nature of evil. In contrast, quite often these spirits can be helpful and even necessary (establishing social and spiritual contact, predicting the future, the ability to work hard). However, the Koryak were 
not able to counter vodka with their authentic means of spiritual protection and social regulation because of the foreign nature of the phenomenon.

The Koryak community did not elaborate any norms or means of control over alcohol consumption, but allowed the intervention into this area of their lives from outside. Here I see a very old and solid Koryak cultural trait: an excuse for a certain moral passivity when the fight for their human souls is going on without their participation. This form of collective conscious generates the following idea: only another outside power can serve as protection from alcohol. The modern expression of this idea can be seen in the wide acceptance of the Protestant religion in the form of the Pentecostal Church. The activity of Pentecostal missionaries is a substitute for traditional Koryak agency, which is today connected with fading traditional ideas. This helps to increase the level of social control in local society. Specific continuity between traditional religious ideas and Pentecostal services supports the Pentecostal claim that they perform a role of social regulation in aboriginal communities. As a result, mediation of contact between the Koryak and the supernatural, along with the social control of a sober lifestyle, is completely in the hands of Protestant missionaries.

\section{NOTES}

1 Author's fieldnotes. The observation took place on June 26-28, 2002 in the town of Evensk and in Gizhiga village, Severo-Evenskiy District, Magadan Region.

2 Konstantin Ivanovich Bauerman - ethnographer, administration employee, lived in Paren' village with Koryak between 1929 and 1932. He created a cooperative, a school and blacksmith's workshop.

3 Parenets - inhabitant of the village Paren'; plural - parentsy.

4 Kamak or okkamak - a wooden amulet that the Koryak wear on coats (kukhlyanka), belts, headdress and tie to the ritual bunches (taynykvyt) (Vdovin 1977; Gorbacheva 1986; 2004; Koryaks... 2006).

5 For example, they do not cry but cheer. Koryak Oksana Petrovna Vachavnayut, born in 1968, told me: "The Koryak depart in fun" (interviewed on June 23, 2006; Evensk town, SeveroEvenskiy District, Magadan Region).

6 Igor' Yevgen'evich Vorobey's fieldnotes. Interviews with Koryak from Verkhniy Paren' village and the town of Evensk, Severo-Evenskiy District, Magadan Region were conducted between September and October 2014.

7 Author's fieldnotes. Interviews with Koryak from Verkhnii Paren' village and the town of Evensk, Severo-Evenskiy District, Magadan Region were conducted in July-August 2002, June 2006, August 2011 and October 2012.

8 I. Y. Vorobey's fieldnotes.

9 Kul'tbasa - a complex settlement with a boarding school, domestic houses, a hospital, workshops, a veterinary station, a trading station and warehouses.

10 Refering to amanita, braga and spirit.

11 Author's fieldnotes. Interviews were conducted on November 8, 2011 in Verkhniy Paren' village, Severo-Evenskiy District, Magadan Region.

12 Author's fieldnotes. Interviews were conducted on June 22, 2006 in the town of Evensk, Severo-Evenskiy District, Magadan Region. 
AIEA - Archive of the Institute of Ethnology and Anthropology of the Russian Academy of Sciences [АИЭА - Архив Института этнологии и антропологии РАН]

F. 44, 1. 7, f. 1109 - Field notes of I. S. Gurvich. Materials of the expedition. Olyutorskiy and Beringovskiy rayons, 1969. [Ф. 44, оп. 7, д. 1109 - Полевая тетрадь И. С. Гурвича. Экспедиционные материалы. Олюторский и Беринговский районы. 1969 г.]

F. 44, 1. 7, f. 1116 - Field notes of I. S. Gurvich. Materials of the expedition KNO, 1971. [Ф. 44, оп. 7, д. 1116 - Полевая тетрадь И. С. Гурвича. Экспедиционные материалы КНО. 1971 г.]

AIVR - Archive of the Institute of Oriental Manuscripts of the Russian Academy of Sciences [АИВР - Архив Института восточных рукописей РАН]

F. 23, 1. 2, f. 128 and 129 - Field diaries of D. L. Brodskaya-Jochelson. [Ф. 23, оп. 2, ддд. 128, 129 - Дневники Д. А. Бродской-Иохельсон.]

GARF - State Archive of the Russian Federation [ГАРФ - Государственный архив Российской Федерации]

F. P-3977, 1. 1, f. 448 - Bauerman, K. I. Cultural-economical situation of the Koryak in Paren'; Orlova, E. P. The Koryak of Kamchatka peninsula. [Ф. Р-3977, оп. 1, д. 448. Бауэрман К. И. Культурно-экономическое состояние пареньских коряков; Орлова Е. П. Коряки полуострова Камчатки.]

F. P-3977, 1. 1, f. 1112 - Organisational report of the manager of the Koryak kul'tbaza for the years 1930-1931. [Ф. Р-3977, оп. 1, д. 1112 - Организационный отчет заведующего Корякской культбазой за 1930-1931 гг.]

RGADA - Russian State Archive of Ancient Acts [РГАДА - Российский государственный архив древних актов]

F. 199, no. 539, 1. 2, f. 6 - “Additions made by captain Shmalev ...”. [Ф. 199, № 539, оп. 2, д. 6. «Прибавление, учиненное капитан[ом] Шмалев[ым]...».]

RGVIA - Russian State Military-Historical Archive [РГВИА - Российский государственный военно-исторический архив]

F. 14808, 1. 1, f. 73 - "Diary of everyday activities by Gizhiginsk castle of mister captain Shmalev ...". [Ф. 14808, оп. 1, д. 73 - «Журнал дневной бытности при Гижигинской крепости господина капитана Шмалева ...».]

\section{REFERENCES}

Antropova, Valentina Vasil'yevna. 1976. Predstavleniya koryakov o rozhdenii, bolezni i smerti. - Priroda i chelovek $v$ religioznykh predstavleniyakh narodov Sibiri i Severa (vtoraya polovina XIX - nachalo XX v.), edited by Innokentiy Stepanovich Vdovin. Leningrad: Nauka, 254-257. [Антропова, Валентина Васильевна. 1976. Представления коряков о рождении, болезни и смерти. - Природа и человек в религиозных представлениях народов Сибири и Севера (вторая половина XIX - начало XX в.), отв. ред. Иннокентий Степанович Вдовин. Денинград: Наука, 254-257].

Beretti, Nikolay Nikolayevich. 1929. Na Kraynem Severo-Vostoke. - Zapiski Vladivostokskogo otdela Gosudarstvennogo Russkogo geograficheskogo obshchestva 4 (21): 5-102. [Беретти, Николай Николаевич. 1929. На Крайнем Северо-Востоке. - Записки Владивостокского отдела Государственного Русского географического общества 4 (21): 5-102.]

Bogoraz, Vladimir Germanovich. 1939. Chukchi. Religiya. Leningrad: Izdatel'stvo Glavsevmorputi. [Богораз, Владимир Германович. 1939. Чукчи. Религия. Ленинград: Издательство Главсевморпути.] 
Bogoraz, Vladimir Germanovich. 1991. Material'naya kul'tura chukchey. Moskva: Nauka. [Богораз, Владимир Германович. 1991. Материальная культура чукчей. Москва: Наука.]

Boyer, Pascal. 1994. Cognitive Constraints on Cultural Representations: Natural Ontologies and Religious Ideas. - Mapping the Mind. Domain Specificity in Cognition and Culture, edited by Lawrence Hirschfeld and Susan Gelman. New York, NY: Cambridge University Press, 391-411.

Durkheim, Emile. 1964 [1895]. The Rules of Sociologocal Method. New York, NY: Free Press.

Durkheim, Emile. 1965 [1915]. The Elementary Forms of the Religious Life. New York, NY: Free Press.

Dedyk, Valentina Romanovna. 2006. Koryak Personal Names. - Sibirica 1 (5): 117-140. DOI: https://doi.org/10.3167/136173606780265243.

Dikov, Nikolay Nikolaevich. 1971. Naskal'nye zagadki dreoney Chukotki: Petroglify Pegtymelya. Moskva: Nauka. [Диков, Николай Николаевич. 1971. Наскальные загадки древней Чукотки: Петроглифы Пегтылеля. Москва: Наука.]

Gorbacheva, Valentina Vladimirovna. 1986. Traditsionnye lichnye i semeynye okhraniteli achayvayamskikh olenevodov. - Sovetskaya etnografiya 5: 104-113. [Горбачева, Валентина Владимировна. 1986. Традиционные личные и семейные охранители ачайваямских оленеводов. - Советская этнография 5: 104-113.]

Gorbacheva, Valentina Vladimirovna. 2004. Obryady i prazdniki koryakov. Sankt-Peterburg: Nauka. [Горбачева, Валентина Владимировна. 2004. Обряды и праздники коряков. СанктПетербург: Наука.]

Gurvich, Il'ya Samuilovich. 1987. Novye dannye po traditsionnoy obryadnosti koryakov. - Traditsionnye verovaniya $i$ byt narodov Sibiri (XIX - nachalo XX v.), edited by Izmail Nukhovich Gemuyev and Andrey Markovich Sagalayev. Novosibirsk: Nauka, 75-84. [Гурвич, Илья Самуидович. 1987. Новые данные по традиционной обрядности коряков. - Традиционные верования и быт народов Сибири (ХIX - начало XX в.), отв. ред. Измаил Нухович Гемуев и Андрей Маркович Сагалаев. Новосибирск: Наука, 75-84.]

Khakhovskaya, Lyudmila Nikolaevna. 2014. Koryakskie ritual'nye svyazki: istoki i interpretatsiya. - Vestnik SVNC DVO RAN 1: 97-106. [Хаховская, Дюдмила Николаевна. 2014. Корякские ритуальные связки: истоки и интерпретация. - Вестник СВНЦ ДВО РАН 1: 97-106.]

Iokhel'son, Vladimir Il'ich. 1997. Koryaki. Material'naya kul'tura i sotsial'naya organizatsiya. SanktPeterburg: Nauka. [Иохельсон, Владимир Ильич. 1997. Коряки. Материальная культура и социальная организациия. Санкт-Петербург: Наука.]

Jochelson, Waldemar. 1905. The Koryak. Religion and Myths. Memoirs of the American Museum of Natural History 6 (1). Leiden; New York, NY: E. J. Brill; G. E. Stechert.

Koryaks: Pioneers of the Tundra. The 21st Special Exhibition. 2006. Hokkaido: Press of Museum of Northern Peoples.

Kurebito, Megumi. 2008. Traditsionnye koryakskie sposoby narecheniya imeni i ikh transformatsiya. - V Dikovskiye chteniya: materialy nauchno-prakticheskoy konferentsii, posoyashchennoy 80-letiyu Pervoy Kolymskoy ekspeditsii i 55-letiyu obrazovaniya Magadanskoy oblasti, edited by Aleksandr Ivanovich Lebedintsev. Magadan: Kordis, 130-133. [Куребито, Мегуми. 2008. Традиционные корякские способы наречения имени и их трансформация. - V Диковские чтения: материаль научно-практической конференции, посвященной 80-летию Первой Кольимской экспедиции и 55-летию образования Магаданской области, отв. ред. Александр Иванович Лебединцев. Магадан: Кордис, 130-133.]

Lebedev, Vladimir Vladimirovich and Yuriy Borisovich Simchenko. 1983. Achayvayamskaya vesna. Moskva: Mysl'. [Лебедев, Владимир Владимирович и Юрий Борисович Симченко. 1983. Ачайваямская весна. Москва: Мысль.]

Merk, Karl. 1978. Opisaniye obychayev i obraza zhizni chukchey. - Etnograficheskiye materialy Severo-Vostochnoy geograficheskoy ekspeditsii: 1785-1795 gg., edited by Innokentiy Stepanovich Vdovin. Magadan: Knizhnoye izdatel'stvo, 98-152. [Мерк, Карл. 1978. Описание обычаев 
и образа жизни чукчей. - Этнографические материаль Северо-Восточной географической экспедиции: 1785-1795 г2., отв. ред. Иннокентий Степанович Вдовин. Магадан: Книжное издательство, 98-152.]

Orlova, Yelizaveta Porfir'yevna. 1929. Koryaki poluostrova Kamchatki. - Severnaya Aziya 3: 83-113. [Орлова, Елизавета Порфирьевна. 1929. Коряки полуострова Камчатки. - Северная Азия 3: 83-113.]

Stebnitskiy, Sergey Nikolaevich. 1930. Koryatskiye deti. - Sovetskiy Sever 4: 39-47. [Стебницкий, Сергей Николаевич. 1930. Коряцкие дети. - Советский Север 4: 39-47.]

Vdovin, Innokentiy Stepanovich. 1977. Religioznye kul'ty chukchey. - Pamyatniki kul'tury narodov Sibiri i Severa, edited by Innokentiy Stepanovich Vdovin. Leningrad: Nauka, 117-171. [Вдовин, Иннокентий Степанович. 1977. Религиозные культы чукчей. - Памятники культуры народов Сибири и Севера, отв. ред. Иннокентий Степанович Вдовин. Аенинград: Наука, 117-171.]

Vdovin, Innokentiy Stepanovich. 1979. Vliyaniye khristianstva na religioznye verovaniya chukchey i koryakov. - Khristianstvo i lamaizm u korennogo naseleniya Sibiri, edited by Innokentiy Stepanovich Vdovin. Leningrad: Nauka, 86-114. [Вдовин, Иннокентий Степанович. 1979. Вдияние христианства на религиозные верования чукчей и коряков. - Христианство и ламаизм у коренного населения Сибири, отв. ред. Иннокентий Степанович Вдовин. Ленинград: Наука, 86-114.]

Vereshchaka, Yelena Andreyevna. 2014. Traditsiya ispol'zovaniya krasnogo muhomora (Po etnograficheskim materialam chukchey, koryakov, itel'menov). - Sibirskiy sbornik 4. Grani sotsial'nogo: Antropologicheskiye perspektivy issledovaniya sotsial' nykh otnosheniy i kul'tury. (Pamyati rossiyskogo etnografa-tungusoveda Nadezhdy Vsevolodovny Ermolovoy), edited by Vladimir Nikolayevich Davydov and Dmitriy Vladimirovich Arzyutov. Sankt-Peterburg: MAE RAN, 326-339. [Верещака, Елена Андреевна. 2014. Традиция использования красного мухомора (По этнографическим материалам чукчей, коряков, ительменов). - Сибирский сборник 4. Грани социильного: Антропологические перспективы исследования социиальных отношений и культуры. (Памяти российского этнографа-тунгусоведа Надежды Всеволодовны Ермоловой), отв. ред. Владимир Николаевич Давыдов и Дмитрий Владимирович Арзютов. СанктПетербург: МАЭ РАН, 326-339.] 